Martin Pracný*

ORCID: 0000-0001-5613-3740

Uniwersytet Masaryka w Brnie

https://doi.org/10.19195/1733-5779.37.11

\title{
Czechosłowacka reforma walutowa z 1945 roku
}

JEL Classification: N14, E42, E52

Słowa kluczowe: Czechosłowacja, reforma walutowa, II wojna światowa

Keywords: Czechoslovakia, monetary reform, World War II

\begin{abstract}
Abstrakt: Niniejszy artykuł dotyczy reformy walutowej, która miała miejsce w 1945 roku w Czechosłowacji. Opracowanie to ma na celu przybliżenie sytuacji monetarnej na obszarach Czechosłowacji po II wojnie światowej, przeanalizowanie przyczyn przeprowadzania reformy walutowej oraz opisanie jej prawnych i technicznych aspektów. Praca udziela odpowiedzi na podstawowe pytanie, czy omawiana reforma była niezbędna w okresie powojennym, a także czy w jej efekcie wystarczająco uregulowano sytuację monetarną w odnowionym państwie.
\end{abstract}

\section{Czechoslovak monetary reform of 1945}

Abstract: This article deals with the monetary reform that took place in 1945 in Czechoslovakia. Its aim is to approximate the monetary situation in the country after World War II, analyze the reasons for conducting a currency reform, as well as describe its legal and technical aspects. The present work answers the basic questions of whether the reform was necessary during the post-war period and whether the monetary situation in the restored state was sufficiently regulated.

\section{Wstęp}

By przedstawić sytuację pieniężną w powojennej Czechosłowacji, należy przybliżyć szerszy kontekst i panujący po wojnie klimat. II wojna światowa była mrocznym rozdziałem historii Czechosłowacji, a także innych państw, których terytoria były okupowane przez III Rzeszę. Wielu ludzi straciło życie, państwo poniosło też duże straty materialne. Szacuje się, że między 1938 a 1945 rokiem zmarło około 350 tys. Czechów i Słowaków. Po wojnie Czechosłowacja zajmowała

\footnotetext{
* Opiekun naukowy (Scientific Tutor) - doc. Ing. Jiř́i Blažek, CSc
} 
znacznie mniejsze terytorium - straciła obszary o łącznej wielkości 12 tys. $\mathrm{km}^{2}$, na których mieszkało około 600 tys. ludzi. Państwo pozbawione zostało między innymi obszarów Rusi Zakarpackiej — przejął je Związek Socjalistycznych Republik Radzieckich (ZSRR)1 ${ }^{1}$ Pozostała część Czechosłowacji została przywrócona w obrębie tych samych granic, które zajmowała w 1938 roku przed układem monachijskim ${ }^{2}$.

Po zakończeniu wojny bardzo istotna okazała się kwestia obywateli narodowości niemieckiej, którzy zamieszkiwali tereny Czechosłowacji. W wyniku decyzji konferencji pokojowych z terenów Czechosłowacji przesiedlono ponad $2 \mathrm{mln}$ Niemców $^{3}$. Planowano również przesiedlenie Węgrów ze Słowacji. Ostatecznie zamierzenie to nie zostało jednak zrealizowane, ponieważ nie otrzymano wsparcia ani ze strony rządu węgierskiego, ani innych państw ${ }^{4}$.

W latach międzywojennych Czechosłowacja była państwem wysoko rozwiniętym pod względem gospodarczym, czego świadomi byli Niemcy. Dlatego też w trakcie wojny wykorzystywali oni wysoki potencjał czeskich fabryk, produkując w nich broń ${ }^{5}$. Fabryki te stały się zatem celem częstego bombardowania przez aliantów. Przykładowo w kwietniu 1945 roku aż w 70\% zniszczono fabrykę Škody w Pilźnie ${ }^{6}$. Niemcy wyzyskiwali również czeską produkcję żywności, w wyniku czego obywatele Protektoratu Czech i Moraw (utworzonego przez III Rzeszę) mieli ograniczony dostęp do produktów spożywczych — wprowadzono reglamentację towarów i kartki na żywność ${ }^{7}$. Sytuacja wyglądała inaczej w przypadku gospodarki Pierwszej Republiki Słowackiej, stworzonej przez Niemców i z nimi współpracującej. Podczas wojny gospodarka ta znajdowała się w bardzo dobrym stanie, co wynikało głównie z możliwości eksportu produktów na rynki państw, będących sojusznikami Rzeszy. Rozwojowi gospodarczemu w państwie słowackim sprzyjało też to, że do 1944 roku nie toczyły się tam działania wojenne.

Ekspertyza szkód wyrządzonych czeskiej gospodarce przez okupację niemiecką została przedstawiona w trakcie procesu Karla Hermanna Franka — jednego z głównych przedstawicieli nazistowskiego terroru na ziemiach czeskich. Raport

1 Do utraty obszarów Rusi Zakarpackiej doszło na podstawie umowy zawartej między czechosłowackim rządem a ZSRR z czerwca 1945 roku.

2 Porozumienie zawarte na konferencji w Monachium w dniach 29-30 września 1938 roku dotyczące przyłączenia części terytoriów Czechosłowacji do Rzeszy Niemieckiej.

${ }^{3}$ Ł. Jasiński, Powojenne rozliczenia w Czechosłowacji 1945-1948. Proces prawny i to polityczne, „Pamięć i Sprawiedliwość” 24, 2014, nr 2, s. 257.

${ }^{4}$ Zamiast całkowitego przesiedlenia dochodziło do sytuacji, w której Węgrzy mieszkający na obszarach Słowacji byli wymieniani za Słowaków mieszkających na Węgrzech.

5 M. Bernášek, Czechoslovak Planning 1945-48, „Soviet Studies” 22, 1974, nr 1, s. 94.

${ }^{6}$ R. Vondra, Penize v moderních českých dějinách, Praha 2012, s. 69.

7 System kartkowy (reglamentacja towarów) w Czechosłowacji został zniesiony dopiero w 1953 roku, wraz z reformą walutową. 
ten wyliczył całkowitą szkodę gospodarczą na 429,7 mld Kč, to jest na kwotę stanowiącą siedmiokrotność dochodu narodowego Czechosłowacji w 1937 roku $^{8}$.

Wraz z końcem wojny konieczne było przywrócenie gospodarki opartej na produkcji, która zabezpieczałaby normalne funkcjonowanie państwa i zaopatrzenie ludności. Zgodnie z celami czechosłowackiego rządu, zdefiniowanymi w Koszyckim programie rządowym ${ }^{9}$, nowa gospodarka miała być zarządzana w wyniku planowania centralnego z ograniczoną własnością prywatną ${ }^{10}$. Ostatnie słowo miało należeć do państwa, które tym razem nie było pod kontrolą niemiecką, lecz radziecką ${ }^{11}$. Jednym z najważniejszych celów czechosłowackiego rządu, w ramach normalizacji handlu i gospodarki w odnowionej powojennej Czechosłowacji, było ponowne wprowadzenie wspólnej czechosłowackiej waluty, która zabezpieczyłaby środki na odbudowę zniszczeń wojennych.

\section{Wielowalutowość na terenach Czechosłowacji}

Sytuacja walutowa na obszarach Czechosłowacji po II wojnie światowej była bardzo skomplikowana ze względu na dużą liczbę różnorodnych walut w obiegu.

Na terenach ustanowionego przez Niemców 16 marca 1939 roku Protektoratu Czech i Moraw w obiegu krążyła korona Protektoratu Czech i Moraw (K). Pieniądze te emitowane były przez Narodowy Bank, który 31 marca 1939 roku powstał z przekształcenia istniejącego wcześniej Narodowego Banku Czechosłowackiego. Ustanowiono sztywny kurs względem niemieckiej marki, zgodnie z którym 1 marka niemiecka równa była 10 koronom ${ }^{12}$. Kurs ten był dla Niemców bardzo korzystny — mogli dzięki niemu kupować zarówno żywność, towary użytku codziennego, jak i towary luksusowe. Co więcej, na obszarach Protektoratu markę niemiecką (Reichmarke, Rentemark itp.) uznawano za akceptowany środek płatniczy ${ }^{13}$.

Ponadto marka niemiecka była głównym środkiem płatniczym na terenach Kraju Sudetów. Obszar ten przed wojną zamieszkiwany był w 85\% przez ludność

${ }^{8}$ F. Vencovský, Vzestupy a propady československé koruny: historie československých měnových pomérü, 1918-1992, Praha 2003, s. 101.

9 Tak zwany program koszycki był deklaracją programową utworzoną przez czechosłowackich komunistów w marcu 1945 roku w Moskwie i następnie zatwierdzoną w słowackich Koszycach.

10 M. Bernášek, op. cit., s. 96.

11 V. Němečková, Československá měnová reforma 1945 — elegantní řešení nebo krach?, [w:] Peněžni reformy a zvraty na území České republiky (po r. 1918): (sborník přispěvků ze stejnojmenné konference Slezské univerzity v Opavě pořádané pod záštitou člena rady ČNB prof. Dr. Ing. Jana Fraita dne 9. listopadu 2005 v Opavě), red. J. Knapík, Opava 2005, s. 79.

12 W rzeczywistości kurs wynosił 6-7 koron Protektoratu Czech i Moraw za 1 markę niemiecką.

13 Z. Šustek, Skryta inflacja w Czechosłowacji w latach 1945-1953, [w:] Psucie pieniadza w Europie Środkowo-Wschodniej od antyku po czasy wspótczesne Białoruś-Litwa-Łotwa-Polska-Stowacja-Ukraina, red. K. Filipow, Warszawa 2006, s. 183. 
narodowości niemieckiej, a we wrześniu 1938 roku przyłączono go do Rzeszy Niemieckiej na podstawie układu monachijskiego ${ }^{14}$.

Na terenach utworzonej 14 marca 1939 roku Pierwszej Republiki Słowackiej, będącej państwem satelickim III Rzeszy, w obiegu znajdowała się korona słowacka (Ks). Waluta ta była emitowana przez Narodowy Bank Słowacki, który powstał 4 kwietnia 1939 roku. Stosunek korony słowackiej do korony Protektoratu Czech i Moraw wynosił 1 do 1 . Natomiast w wypadku kursu waluty słowackiej do marki niemieckiej początkowo wynosił on 10 koron równych 1 marce. Kurs wzrósł jednak 1 października 1940 roku do 11,628 korony równych 1 marce ${ }^{15}$. Oznaczało to, że kurs obowiązujący na Słowacji był jeszcze korzystniejszy dla Niemców niż ten obowiązujący na terenach Protektoratu Czech i Moraw. W efekcie Niemcy bardzo chętnie i szeroko korzystali ze słowackich towarów ${ }^{16}$.

Na obszarach Słowacji zajętych w 1938 roku przez Węgrów w obiegu znajdowała się waluta pengö. Natomiast we wschodniej części czechosłowackiego Śląska Cieszyńskiego, pierwotnie zajętego przez Polaków w 1938 roku, w obiegu można było znaleźć polskie złote. Ponadto od 1945 roku na terenach Czechosłowacji w obiegu wciąż znajdowały się bony koronowe, które wykorzystywano do kupna potrzebnego towaru przez wojska radzieckie i czechosłowackie. Korzystały z nich także czechosłowackie urzędy państwowe. Bony zaprojektowano w 1944 roku i wprowadzono do obiegu decyzją Czechosłowackiego Urzędu Walutowego rządu na uchodźstwie w Londynie. Drukowano je w radzieckiej wytwórni papierów wartościowych „Goznak” w Moskwie. Na Słowacji bony stały się prawnym środkiem płatniczym od 13 marca 1945 roku, natomiast na pozostałych obszarach Czechosłowacji obowiązywały od 19 maja $1945 \mathrm{roku}^{17}$. Ponadto armia radziecka przywiozła do Czechosłowacji kolejną walutę — rubla radzieckiego. Jednocześnie armia amerykańska przychodząca do Czechosłowacji z zachodu korzystała $\mathrm{z}$ alianckich bonów markowych. W minimalnej ilości w obiegu znajdowały się również waluty państw, przez które przechodziły wojska alianckie wyzwalające czechosłowackie tereny. Ostatecznie walut tych nie uznano za prawne środki płatnicze obowiązujące na obszarach Czechosłowacji, jednakże początkowo były akceptowane i wymieniane przez banki ${ }^{18}$.

W dodatku wciąż wielu ludzi posiadało przedwojenne korony czechosłowackie, wprowadzone w 1919 roku w wyniku reformy walutowej, przeprowadzonej przez ówczesnego ministra skarbu Aloisa Rašína.

Podsumowując, na terenach Czechosłowacji po wojnie w obiegu znajdowało się kilka różnych walut. Każda z nich powiązana była z inną polityką emisyjną, miała

\footnotetext{
${ }^{14}$ M. Bernášek, op. cit., s. 94.

15 W. Morawski, Zarys powszechniej historii pieniadza i bankowości, Warszawa 2002, s. 339.

16 F. Vencovský, Vzestupy a propady československé koruny..., s. 102.

17 R. Vondra, op. cit., s. 72.

18 V. Němečková, op. cit., s. 81.
} 
swoją własną funkcję monetarną i inny kurs. Przed czechosłowackim rządem stało zatem wyzwanie poradzenia sobie z problemem wielowalutowości. Zadania rządu określały cztery cele:

1. jak najszybsze pozbycie się z obiegu okupacyjnych walut na terytorium całego państwa;

2. wprowadzenie nowej wspólnej waluty, która zastąpiłaby słowacką koronę i koronę Protektoratu Czech i Moraw;

3. wyeliminowanie inflacyjnej nadwyżki pieniędzy, która powstała w czasie wojny;

4. skonsolidowanie nowej waluty czechosłowackiej i wzmocnienie gospodarki przez politykę pieniężną ${ }^{19}$.

\section{Unifikacja obiegu pieniędzy}

W celu przywrócenia stabilności gospodarce konieczne było rozwiązanie problemów walutowych. Na terytorium byłego Protektoratu Czech i Moraw rozporządzeniem Czeskiej Rady Narodowej z dnia 10 maja 1945 roku wycofano z obiegu markę niemiecką. Natomiast już dnia 19 maja 1945 roku rząd wydał nowe rozporządzenie $^{20}$, które regulowało szerszy zakres spraw i określało obieg pieniędzy. Marka niemiecka w rzeczywistości przestała być środkiem płatniczym już wcześniej — w momencie opublikowania okólnika Narodowego Banku z dnia 28 kwietnia 1945 roku, w którym bank ogłosił koniec przyjmowania marki niemieckiej od osób samozatrudnionych, wskutek czego waluta ta straciła zaufanie w społeczeństwie. Rozporządzeniem Ministerstwa Skarbu z dnia 29 maja 1945 roku ${ }^{21}$ ustalono, że marki niemieckie będą przyjmowane przez określone urzędy od 6 do 14 czerwca 1945 roku, a następnie będą umieszczane na rachunkach zablokowanych, co nie dawało ludziom gwarancji zwrotu wniesionych przez nich kwot. Ustanowiony został nowy kurs wymiany - 1 marka niemiecka równa była 10 koronom Protektoratu Czech i Moraw. Działania te doprowadziły do szybkiego wycofania marek niemieckich z obszaru byłego Protektoratu Czech i Moraw.

Natomiast w Kraju Sudetów, będącym przez siedem lat częścią III Rzeszy, o wycofaniu marki niemieckiej zdecydowano później — w terminie od 1 do 10 sierpnia 1945 roku. Władzy zależało na tym, by nie zakłócać życia gospodarczego, jednocześnie koordynując wymianę waluty z postępem armii, wyzwalającej obszary Czechosłowacji. Dla osób narodowości słowiańskiej kurs wymiany waluty wynosił: 1 marka niemiecka równa 10 koronom Protektoratu Czech i Moraw z limitem wymiany do 100 marek niemieckich. Natomiast dla Węgrów, Niemców

19 F. Vencovský, Vzestupy a propady československé koruny..., s. 111.

20 Nařízení vlády č. 7/1945 Sb., o platidlech v zemích České a Moravskoslezské.

21 Vyhláška ministerstva financí č. 12/1945 Ú. 1., o platidlech markové měny. 
i osób uznanych przez państwo za wrogie kurs wymiany też wynosił: 1 marka niemiecka równa 10 koronom Protektoratu Czech i Moraw, przy czym ustawiono znacznie niższy limit wymiany — w wysokości 30 marek niemieckich. Pozostałe marki zostawały deponowane.

Na mocy rozporządzenia Prezydium Słowackiej Rady Narodowej ${ }^{22}$ na obszarze Słowacji w obiegu pozostała korona słowacka. Na terenach okupowanych przez Węgry od 1938 roku, na podstawie rozporządzenia Słowackiej Rady Narodowej z dnia 19 marca 1945 roku $^{23}$, wycofywano pieniądze węgierskie — kurs wynosił 2 korony słowackie równe 1 pengö, z limitem wymiany w wysokości 1000 pengö na osobę. Waluta pengö przestała obowiązywać jako prawny środek płatniczy na Słowacji 26 czerwca 1945 roku $^{24}$. Na Słowacji przeprowadzono także przestemplowanie banknotów, którego celem była ewidencja pieniędzy znajdujących się w obiegu. Przestemplowanie miało dodatkowo zapobiec możliwemu niewłaściwemu wykorzystaniu nielegalnie przetransportowanych poza granicę banknotów. Banknoty te zabierali z sobą uciekający przedstawiciele państwa słowackiego ${ }^{25}$. Radziecki rubel był akceptowany do listopada 1945 roku — wówczas wojska radzieckie opuściły teren Czechosłowacji, kurs wynosił 1 rubel równy 10 koronom.

Wskutek wymienionych działań na terenach powojennej Czechosłowacji udało się wyeliminować różnorodność znajdujących się w obiegu walut, a także zmniejszono liczbę gotówki w obiegu. Stworzono dwa obszary monetarne - na ziemiach czeskich w obiegu znajdowała się korona Protektoratu Czech i Moraw, natomiast na Słowacji korona słowacka. Między tymi dwiema walutami ustawiono kurs 1 do $1^{26}$. Korona słowacka nie była środkiem płatniczym na terytorium ziem czeskich, a korona Protektoratu Czech i Moraw nie była środkiem płatniczym na Słowacji — wzajemne płatności były więc dokonywane w ramach specjalnego systemu rozliczeń. Ludzie podróżujący z ziem czeskich na Słowację lub odwrotnie mieli możliwość wolnego przydziału pieniędzy po kursie w wysokości 1 do $1^{27}$.

Jednocześnie jedynym wspólnym środkiem płatniczym obowiązującym w obu częściach Czechosłowacji były koronowe bony Czechosłowackiego Urzędu Walutowego przybyłe wraz z armią radziecką. Kurs bonów wynosił 1 do 1 w odniesieniu do korony słowackiej i korony Protektoratu Czech i Moraw.

22 Nariadenie predsedníctva Slovenskej národnej rady č. 14/1945 Sb., o obehu československých platidiel.

${ }^{23}$ Nariadenie Slovenskej národnej rady č. 13/1945 Sb., o výmennom kurze pengö.

24 Z. Šustek, op. cit., s. 189.

25 Z. Kalabis, Když koruny létaly v bombardérech, www.mesec.cz/clanky/kdyz-koruny-letalyv-bombarderech-stripky-z-historie-ceskoslovenskych-penez/ (dostęp: 2.04.2020).

26 W. Morawski, op. cit., s. 339.

27 V. Tomšík, 100 let česko-slovenské koruny: měnová politika, instituce, penize, Plzeň 2018, s. 28. 
Ze względu na brak pieniędzy o małej wartości nominalnej zdecydowano o przywróceniu niektórych przedwojennych czechosłowackich monet. Ponadto na ziemiach czeskich odnowiono ważność niektórych czechosłowackich przedwojennych banknotów.

\section{Odbudowa bankowości centralnej}

Już 12 listopada 1944 roku, podczas wojny, wydany został dekret Prezydenta Republiki na uchodźstwie w sprawie zarządzania walutą i wydawania gotówki na wyzwolonym terytorium ${ }^{28}$. Na podstawie tego dekretu powstał Czechosłowacki Urząd Walutowy. Był on uprawniony do wydawania pieniędzy dla armii czechosłowackiej, administracji cywilnej, oddziałów sojuszniczych oraz organizacji międzynarodowych działających na wyzwolonym terytorium, a także mógł prowadzić na nim wymianę pieniędzy. Na podstawie rozporządzenia rządowego mógł nawet pełnić funkcję banku centralnego ${ }^{29}$.

Po utworzeniu dwóch obszarów monetarnych z koroną Protektoratu Czech i Moraw i z koroną słowacką w 1945 roku przy unifikacji obiegu pieniędzy nadal istniały dwie instytucje emisyjne. Narodowy Bank ${ }^{30}$, który zarządzał aktywami Narodowego Banku dla Czech i Moraw oraz Narodowy Bank Słowacki. Zmianą w dotychczasowym zarządzaniu Narodowym Bankiem było wprowadzenie jako najwyższego organu statutowego administracji tymczasowej mianowanej przez rząd. W administracji tymczasowej zasiadali zarówno Czesi, jak i Słowacy ${ }^{31}$. Dopiero na podstawie dekretu Prezydenta Republiki z dnia 19 października 1945 roku $^{32}$ doszło do połączenia niezależnych instytucji i odnowienia Narodowego Banku Czechosłowackiego. Główna siedziba banku mieściła się w Pradze, natomiast na Słowacji utworzono oddział regionalny w Bratysławie.

\section{Nowa czechosłowacka korona}

Unifikacja obiegu pieniędzy w Czechosłowacji i przywrócenie Narodowego Banku Czechosłowackiego pozwoliły na wprowadzenie nowej wspólnej waluty. Istotne było również wyeliminowanie inflacyjnej nadwyżki siły nabywczej, która powstała przez finansowanie wydatków wojskowych przez rząd niemiecki oraz

28 Dekret presidenta republiky č. 16/1944 Úředního věstníku československého, o správě měny a vydávání platidel na osvobozeném území.

29 Československý měnový úr̆ad, www.historie.cnb.cz/cs/dejiny_instituce/narodni_banka_ pro_cechy_a_moravu/ceskoslovensky_menovy_urad.html (dostęp: 2.04.2020).

${ }_{30}$ Bank ten celowo nazwano Narodowym Bankiem bez oznaczenia miejsca jego działania ze względu na niepewną sytuację jego funkcjonowania na terenach Słowacji.

31 F. Vencovský, Dëjiny bankovnictví v Českých zemích, Praha 1999, s. 406.

32 Dekret presidenta republiky č. 139/1945 Sb., o přechodné úpravě právních poměrů Národní banky Československé. 
przez monetarną eksploatację czeskiej i słowackiej gospodarki. Inflacyjną nadwyżkę siły nabywczej prezentuje tabela 1 .

Tabela 1. Ilość pieniędzy w Czechosłowacji przed i po II wojnie światowej

\begin{tabular}{|c|c|c|}
\hline Data & $\begin{array}{c}\text { Gotówka w obiegu } \\
{[\mathrm{mld} \text { Kč }]}\end{array}$ & $\begin{array}{c}\text { Depozyty } \\
\text { gospodarstw } \\
{[\mathrm{mld} \mathrm{Kč]}}\end{array}$ \\
\hline koniec roku 1937 & 8,3 & 85,0 \\
\hline koniec roku 1938 & 14,4 & 61,6 \\
\hline 31 października 1945 & 123,5 & 208,0 \\
\hline
\end{tabular}

Źródło: F. Vencovský, Vzestupy a propady československé koruny..., s. 113.

Narzucone przez władze Protektoratu Czech i Moraw ceny urzędowe towarów wykazywały podczas wojny wzrost $60-70 \%$ w porównaniu do cen przedwojennych. Na Słowacji inflacja była jeszcze większa — pod koniec wojny poziom cen był 30-50\% wyższy niż na ziemiach czeskich. Na Słowacji jednak różnica między cenami urzędowymi a cenami na czarnym rynku była mniejsza ${ }^{33}$.

Techniczne przygotowanie reformy walutowej było bardzo wymagające. Dlatego też doszło do niej dopiero kilka miesięcy po ujednoliceniu walut. Ministerstwo Skarbu, na drodze porozumienia z Narodowym Bankiem, złożyło propozycję reformy walutowej. Propozycja ta stała się podstawą działań ekspertów i polityków, którzy opracowali ostateczną wersję reformy ${ }^{34}$. Dnia 19 października 1945 roku, po długich obradach wydany został dekret Prezydenta Republiki w sprawie odnowienia waluty czechosłowackiej ${ }^{35}$. Dekret określał, że od dnia 1 listopada 1945 roku wprowadzona zostanie nowa czechosłowacka korona, oznaczana skrótem Kčs, która dzielić się będzie na 100 halerzy ${ }^{36}$. Nowa czechosłowacka korona zastąpiła istniejącą dotychczas koronę Protektoratu Czech i Moraw, koronę słowacką oraz przedwojenną koronę czechosłowacką. Ustanowiono kurs wymiany w stosunku 1 do 1 . Jednocześnie znajdujące się w obiegu koronowe bony wyemitowane przez Czechosłowacki Urząd Walutowy przestały być środkiem płatniczym na terenie Czechosłowacji ${ }^{37}$.

Każda osoba mogła wymienić pieniądze do maksymalnej kwoty 500 Kčs w jednym z 15 tys. miejsc do tego przeznaczonych. Pozostałe kwoty były deponowane na rachunkach zablokowanych i nie można było nimi swobodnie dysponować. Działanie to uzasadnione było chęcią celowego zmniejszenia liczby pieniędzy

33 V. Tomšík, op. cit., s. 27.

34 Ibidem, s. 27.

35 Dekret presidenta republiky č. 91/1945 Sb., o obnovení československé měny.

36 Czechosłowacka korona, którą wprowadzono podczas reformy w 1919 roku, miała natomiast skrót Kč.

37 W. Morawski, op. cit., s. 339. 
w obiegu. Do zwrotu pieniędzy umieszczonych na kontach zablokowanych miało dojść po ustabilizowaniu gospodarki i zniesieniu systemu racjonowania ${ }^{38}$.

Względem przedsiębiorstw wprowadzono specjalną procedurę. Mogły one dokonywać wymiany starych pieniędzy na nowe zgodnie z ich potrzebami gospodarczymi. Prawo do pełnej wymiany miały jedynie armie alianckie oraz przedstawiciele dyplomatyczni.

Dnia 20 października 1945 roku wydano rozporządzenie ministra skarbu w sprawie nowych środków płatniczych czechosłowackiej waluty ${ }^{39}$. Rozporządzeniem tym wprowadzono do obiegu pieniądze papierowe, które już w 1942 roku zamówione zostały $\mathrm{w}$ angielskich drukarniach przez czechosłowacki rząd na uchodźstwie ${ }^{40}$. Omawiane bilety skarbowe ${ }^{41}$ przechowywane były przez trzy lata $\mathrm{w}$ angielskich podziemnych schronach w pobliżu Bristolu, a następnie we wrześniu 1945 roku zostały przeniesione do Czechosłowacji. Bilety skarbowe miały nominały o wartościach $1000,500,100,50,20,10$ oraz 5 Kčs. Ponadto do obiegu wprowadzone zostały banknoty o wartości nominalnej 1000 Kčs oraz bilety skarbowe o wartości 100 Kčs, które wydrukowała drukarnia Narodowego Banku już w Czechosłowacji. Zgodnie z rozporządzeniem Ministerstwa Skarbu z dnia 20 października 1945 roku bilety skarbowe powyżej 100 Kčs uznawane były za banknoty Narodowego Banku Czechosłowackiego ${ }^{42}$.

W rzeczywistości nie wszystkie dawne środki płatnicze zostały zastąpione nowymi koronami w ramach reformy. Jako że nie można było produkować bilonu, w obiegu pozostały wszystkie dotychczasowe monety.

Zgodnie z dekretem Prezydenta Republiki z dnia 20 października 1945 roku $^{43}$ kazano zarejestrować w instytucjach finansowych wszystkie depozyty pieniężne (konta oszczędnościowe) i inne należności pieniężne, a także ubezpieczenia na życie i papiery wartościowe. Ich los był taki sam jak w przypadku gotówki — zostały zdeponowane przez państwo i nie można było nimi dysponować.

Na mocy dekretów zdefiniowano również stosunek korony do niektórych walut światowych, ustanawiając kurs wymiany na dolara amerykańskiego ${ }^{44}$. Porównując ceny wewnętrzne z cenami na zachodzie ustalono, że 50 Kčs będzie miało wartość 1 dolara $^{45}$. Została również określona wartość korony w stosunku do złota, definiowana na podstawie zawartości złota w dolarach -1 była równa

38 Z. Šustek, op. cit., s. 194.

39 Vyhláška ministra financí č. 92/1945 Sb., o nových platidlech československé měny.

40 Powojenna reforma walutowa była systematycznie przygotowywana przez czechosłowacki rząd na uchodźstwie w Anglii od 1941 roku.

41 Nazywane były biletami skarbowymi ze względu na to, że ich emisją zajmowało się państwo, a nie bank centralny.

42 F. Vencovský, Vzestupy a propady československé koruny..., s. 103-104.

43 Dekret presidenta republiky č. 95/1945 Sb., o přihlášení vkladů a jiných peněžních pohledávek u peněžních ústavů, jakož i životních pojištění a cenných papírů.

44 E. Rose, Reforma walutowa w Czechosłowacji, „Komunikat — Instytut Śląski” 1947, nr 6, s. 3.

45 W roku 1937 kurs wynosił 1 dolar równy 28,69 Kč. 
0,0177734 grama złota. Decyzja o zdefiniowaniu wartości korony w stosunku do niektórych walut światowych wiązała się ze wstąpieniem Czechosłowacji po II wojnie światowej do dwóch organizacji, mających pomagać państwom zniszczonym przez wojnę $w$ ich odbudowie, a także mających za zadanie wspieranie rozwoju handlu międzynarodowego. Były to: Międzynarodowy Fundusz Walutowy i Bank Światowy ${ }^{46}$.

Konieczne było też dostosowanie cen, które podczas wojny w różnych częściach Czechosłowacji były odmienne ${ }^{47}$. Wynagrodzenia i płace ustanowiono na poziomie trzykrotnie wyższym w stosunku do wartości nominalnej z 1939 roku. W ciągu sześciu lat okupacji jednak siła nabywcza waluty spadła do około 1/12 wartości sprzed wojny, co wiązało się ze znacznym spadkiem poziomu życia w Czechosłowacji w porównaniu do czasów przedwojennych ${ }^{48}$.

\section{Podsumowanie rezultatów reformy walutowej}

Można stwierdzić, że reforma walutowa była nie do uniknięcia. Wymiana pieniędzy oraz zatrzymanie depozytów na rachunkach zablokowanych oznaczały dla gospodarki czechosłowackiej odcięcie się od konsekwencji wojny, a przez to możliwość nowego startu. Wymieniono łącznie 19 mld Kčs, które zastąpiły 124 mld starych pieniędzy. Do dnia 15 listopada 1945 roku na rachunkach zablokowanych zarejestrowano łącznie 258 mld Kčs. Udział ziem czeskich w całkowitej zablokowanej kwocie wynosił 232,2 mld Kčs, natomiast udział Słowacji wynosił 23,8 mld Kčs ${ }^{49}$. Procedura likwidacji tych depozytów nie została jednak skonkretyzowana, co miało niezwykle negatywny wpływ na wynik całej reformy. Odzyskanie zablokowanych pieniędzy, zdeponowanych na rachunkach, możliwe było w wyjątkowych okolicznościach, takich jak na przykład organizacja ślubu, narodziny dziecka, leczenie czy też inwalidztwo ${ }^{50}$. Fundusze te udostępniano również przedsiębiorstwom na potrzeby gospodarcze, takie jak wypłaty wynagrodzeń i niezbędne wydatki, związane z funkcjonowaniem przedsiębiorstwa ${ }^{51}$. Narodowy Bank otrzymywał aż 700 wniosków dziennie o uwolnienie zdeponowanych środków, przez co między drugim a trzecim tygodniem listopada 1945 roku obieg pieniędzy zwiększył się o $66,5 \mathrm{mln} \mathrm{Kčs}^{52}$.

46 K. Horsefield, The International Monetary Fund 1945-1965: Twenty Years of International Monetary Cooperation Volume I: Chronicle, Washington D.C. 1969, s. 94-96.

47 B.P. Pesek, Monetary Reform and Monetary Equilibrium, ,Journal of Political Economy” 66, 1958, nr 5, s. 384.

48 R. Vondra, op. cit., s. 73.

49 V. Němečková, op. cit., s. 89.

50 Prawo do odzyskania swoich zdeponowanych pieniędzy miały także partie polityczne, instytucje publiczne oraz przedstawiciele zagraniczni.

51 F.H. Klopstock, Monetary Reform in Liberated Europe, „The American Economic Review” 36, 1946, nr 4, s. 587.

52 V. Němečková, op. cit., s. 90. 
W celu likwidacji zdeponowanych pieniędzy, ustawą z dnia 15 kwietnia 1946 roku $^{53}$ wprowadzono dwie nadzwyczajne jednorazowe daniny — daninę z majątku oraz daninę od przyrostu wartości majątku. Wpływy z tych jednorazowych danin miały na celu finansowanie emisji pieniędzy, które były uwalniane $\mathrm{z}$ rachunków zablokowanych. Drugorzędnym celem opisywanych danin było zidentyfikowanie ludzi, którzy wzbogacili się na wojnie. Daniny miały być opłacane gotówką, z pieniędzy z zablokowanych rachunków lub krajowych papierów wartościowych. Całkowity dochód z danin wyniósł jedynie około 35 mld Kčs ${ }^{54}$. Ta kwota była jednak niewystarczająca, aby móc rozwiązać problem zdeponowanych środków na zablokowanych rachunkach.

Ustawą z dnia 2 lipca 1947 roku $^{55}$ założony został Likwidacyjny Fundusz Walutowy, który miał zapewnić całkowitą likwidację deponowanych na rachunkach zablokowanych pieniędzy za pomocą wyżej wymienionych nadzwyczajnych danin oraz skonfiskowanego majątku należącego do obywateli państw nieprzyjacielskich.

Do obiegu stale trafiało więcej nowo emitowanych banknotów. Dwa lata po rozpoczęciu reformy ilość gotówki w obiegu potroiła się, a kwota na rachunkach bieżących wzrosła 1,5 raza ${ }^{56}$. Narodowy Bank emitował nowe pieniądze przy użyciu tradycyjnych metod, takich jak wykupywanie od ludności papierów wartościowych, dyskonta weksli i zakup walut obcych. Metod tych użyto jednak jedynie w $10 \%$ emisji. Reszta koron emitowana była w wyniku uwolnienia deponowanych na zablokowanych rachunkach pieniędzy. Pod koniec 1949 roku na rachunkach zablokowanych było już tylko 120 mld Kčs ${ }^{57}$. Emisja banknotów utraciła podstawowe powiązanie z tworzeniem rzeczywistej siły nabywczej korony. W większości przypadków pieniądze wprowadzone do obiegu nie miały pokrycia w oferowanych towarach i usługach. Miała na to wpływ nowo wprowadzona gospodarka centralnie planowana. W normalnych warunkach wzrost tej nierówności znalazłby odzwierciedlenie w podwyżkach $\operatorname{cen}^{58}$. Ze względu na to, że poziom cen i płac zarządzany był przez państwo, inflacja miała charakter inflacji ukrytej ${ }^{59}$. Jako że nie było możliwości wykorzystania pieniędzy, społeczeństwo zaczęło je gromadzić (zob. tabela 2).

53 Zákon č. 134/1946 Sb., o dávce z majetkového přírůstku a o dávce z majetku.

54 Nie udało się osiągnąć większej kwoty ze względu na umiejętne obejście przepisów przez obywateli.

55 Zákon č. 141/1947 Sb., o Likvidačním fondu měnovém.

56 V. Tomšík, op. cit., s. 29.

57 F. Vencovský, Vzestupy a propady československé koruny..., s. 116.

58 B.P. Pesek, op. cit., s. 380.

59 Inflacja ukryta wyrażona jest w trwałej nadwyżce popytu nad ograniczoną podażą dóbr i usług przy administracyjnie regulowanym poziomie cen rynkowych. 
Tabela 2. Rozwój nowej waluty i depozytów gospodarstw domowych po 1945 roku

\begin{tabular}{|c|c|c|}
\hline Data & $\begin{array}{c}\text { Gotówka w obiegu } \\
{[\text { mld Kč }]}\end{array}$ & $\begin{array}{c}\text { Depozyty } \\
\text { gospodarstw } \\
\text { [mld Kč] }\end{array}$ \\
\hline po reformie w 1945 roku & 18,5 & - \\
\hline koniec 1945 roku & 30 & 0,8 \\
\hline koniec 1946 roku & 46,5 & 15,2 \\
\hline koniec 1947 roku & 61 & 27,5 \\
\hline koniec 1948 roku & 72 & 33,6 \\
\hline
\end{tabular}

Źródło: F. Vencovský, Dějiny bankovnictví v Českých zemich..., s. 594.

Na negatywną sytuację walutową miały również wpływ inne czynniki inflacyjne, takie jak finansowanie deficytów rządowych przez emisje pieniężne, likwidacja rynku finansowego oraz centralizacja banków ${ }^{60}$. Brak określenia stałej koncepcji polityki pieniężnej państwa w ramach nowej orientacji gospodarczej spowodował, że inflacyjny problem waluty przed przeprowadzeniem reformy utrzymywał się także po wprowadzeniu nowej waluty. Wkrótce więc konieczna stała się dalsza reforma walutowa, którą przeprowadzono w 1953 roku.

\section{Bibliografia}

\section{Literatura}

Bernášek M., Czechoslovak Planning 1945-48, „Soviet Studies”22, 1974, nr 1, s. 94-109.

Československý měnový úr̆ad www.historie.cnb.cz/cs/dejiny_instituce/narodni_banka_pro_ce chy_a_moravu/ceskoslovensky_menovy_urad.html.

Horsefield K., The International Monetary Fund 1945-1965: Twenty Years of International Monetary Cooperation Volume I: Chronicle, Washington, D.C. 1969.

Jasiński Ł., Powojenne rozliczenia w Czechosłowacji 1945-1948. Proces prawny i tło polityczne, „Pamięć i Sprawiedliwość” 24, 2014, nr 2, s. 253-282.

Kalabis Z., Když koruny létaly v bombardérech, www.mesec.cz/clanky/kdyz-koruny-letaly-v-bom barderech-stripky-z-historie-ceskoslovenskych-penez/.

Klopstock F.H., Monetary Reform in Liberated Europe, „The American Economic Review” 36, 1946, nr 4, S. 578-595.

Morawski W. Zarys powszechniej historii pieniądza i bankowości, Warszawa 2002.

Němečková V., Československá měnová reforma 1945 — elegantní řešení nebo krach?, [w:] Peněžni reformy a zvraty na území České republiky (po r. 1918): (sbornik přispěvkủ ze stejnojmenné konference Slezské univerzity v Opavě pořádané pod záštitou člena rady ČNB prof. Dr. Ing. Jana Fraita dne 9. listopadu 2005 v Opavě), red. J. Knapík, Opava 2005.

${ }^{60}$ F. Vencovský, Tři měnové reformy pro jednu generaci, [w:] Fenomén Stalin: náhoda nebo nevyhnutelnost?; Padesát let od měnové reformy: sbornik textů, red. M. Loužek, Praha 2003, s. 124.

Studenckie Prace Prawnicze, Administratywistyczne i Ekonomiczne 37, 2021

(C) for this edition by CNS 
Pesek B.P., Monetary Reform and Monetary Equilibrium, „Journal of Political Economy” 66, 1958, nr 5, s. 375-388.

Rose E., Reforma walutowa w Czechosłowacji, „Komunikat — Instytut Śląski” 1947, nr 6, s. 1-4.

Ruśkowski E., Finanse publiczne i prawo finansowe. Instrumenty prawnofinansowe $i$ warunki ich stosowania, Białystok 2018.

Šustek Z., Skryta inflacja w Czechostowacji w latach 1945-1953, [w:] Psucie pieniadza w Europie Środkowo-Wschodniej od antyku po czasy współczesne Białoruś-Litwa-Lotwa-Polska-Stowacja-Ukraina, red. K. Filipow, Warszawa 2006, s. 182-202.

Tomšík V., 100 let česko-slovenské koruny: měnová politika, instituce, penize, Plzeň 2018.

Vencovský F., Dějiny bankovnictvív Českých zemích, Praha 1999.

Vencovský F., Tři měnové reformy pro jednu generaci, [w:] Fenomén Stalin: náhoda nebo nevyhnutelnost?; Padesát let od měnové reformy: sbornik texti̊, red. M. Loužek, Praha 2003.

Vencovský F., Vzestupy a propady československé koruny: historie československých měnových pomérů, 1918-1992, Praha 2003.

Vondra R., Penize v moderních českých dějinách, Praha 2012.

\section{Akty normatywne}

Dekret presidenta republiky č. 16/1944 Úředního věstníku československého, o správě měny a vydávání platidel na osvobozeném území.

Dekret presidenta republiky č. 91/1945 Sb., o obnovení československé měny.

Dekret presidenta republiky č. 95/1945 Sb., o přihlášení vkladů a jiných peněžních pohledávek u peněžních ústavů, jakož i životních pojištění a cenných papírů.

Dekret presidenta republiky č. 139/1945 Sb., o přechodné úpravě právních poměrů Národní banky Československé.

Nariadenie Slovenskej národnej rady č. 13/1945 Sb., o výmennom kurze pengö.

Nariadenie predsedníctva Slovenskej národnej rady č. 14/1945 Sb., o obehu československých platidiel.

Nařízení vlády č. 7/1945 Sb., o platidlech v zemích České a Moravskoslezské.

Vyhláška ministerstva financí č. 12/1945 Ú. 1., o platidlech markové měny.

Vyhláška ministra financí č. 92/1945 Sb., o nových platidlech československé měny.

Zákon č. 134/1946 Sb., o dávce z majetkového přírůstku a o dávce z majetku.

Zákon č. 141/1947 Sb., o Likvidačním fondu měnovém.

Studenckie Prace Prawnicze, Administratywistyczne i Ekonomiczne 37, 2021

(C) for this edition by CNS 
